\title{
The Eurasian Economic Union: Integration Without Liberalization?
}

\begin{abstract}
The Eurasian Economic Union (EaEU) came into being in 2015 with the ostensible goal of increasing integration among its member states. An implicit assumption behind this goal was to further trade liberalization, at least within the bloc, as a means to promote additional trade. This paper assesses the development of the EaEU against this promise. Going beyond an analysis of the dynamics of mutual trade, the main focus of this paper is to understand the EaEU's institutional processes, examining if the commitments and framework put in place by the EaEU could actually contribute to trade liberalization. Focusing on the trade policies at the level of the EaEU and the political economy of protectionism, our assessment is not favorable. In particular, the charge that the EaEU remains a geopolitical rather than economic project rings true, as trade liberalization has been halting in individual member states and across the bloc as a whole. This reality is further illustrated in the external trade policies of the Union, most prominently in trade agreements concluded with Vietnam, Iran, Singapore and Serbia, and relations with other major trade partners. The paper argues that, in line with often overlooked theoretical predictions, the institutional framework of the EaEU is not robust enough to ensure that integration processes actually deliver on their stated objectives.
\end{abstract}

Keywords: trade liberalization; Eurasian Union; regional integration; non-tariff barriers

JEL Codes: F15; F42; F55 


\section{Introduction}

The Eurasian Economic Union (EaEU) of Russia, Kazakhstan, Belarus, Armenia, and Kyrgyzstan was constituted via treaty and came into force in January 2015 as a vehicle for bringing together these countries economically, despite differing views on the desirability for further political integration (Sergei 2018). Emulating the experience of the European Union (EU) in the path to economic integration, the EaEU has attempted to not just abolish barriers to interstate trade but also facilitate positive action to harmonize regulatory requirements, adopting policies to foster genuinely free movement within the Union territory and laying out a de facto roadmap for integration over a ten-year period (2015-2025). Bearing in mind that the removal of tariffs and the elimination of customs controls between countries was already initiated with the Customs Union (CU) between Russia, Kazakhstan and Belarus in 2010, it can be argued that the EaEU's added value lies in consolidating the existing trade regime and moving it forward via "deeper" integration, that is the removal of non-tariff barriers and the provision of a common regulatory framework.

Judged solely in terms of speed, the EaEU has made impressive strides in increasing economic integration across the region, albeit building on much older interconnections which never really disappeared during the post-Soviet transition. This has included some very visible successes, such as the facilitation of free movement of people across the vast Eurasian space via a single labor market (Vinokurov 2018). At the same time, however, trade patterns within the EaEU have been erratic at best (Gurova 2018), reflecting the dominance of Russia at the center of the Union and the fact that its own interests in trade and investment lay outside of its tiny Union neighbors (Vinokurov 2017).

These disappointing results in intra-Union trade appear to be driven mainly by economic liberalization lagging behind while regional integration in the Eurasian space has increased. By liberalization, we refer to the commonly-understood idea of opening of markets and, especially, the removal of price, trade, and regulatory barriers; on the other hand, integration can refer to such processes across national borders but also with an eye on harmonization of policies, convergence of economic governance structures and, often, the creation of common institutions to oversee conflict and cooperation. Such an outcome as seen today in the EaEU, where liberalization has fallen behind the project of integration, is in line with what has been observed in other regional groupings without a strong history of trade liberalization at the member state level (see especially the example of Mercosur as detailed in Baer et al. [2002]). Indeed, countries engage in regional integration for a variety of reasons, often associated with political or security considerations (Damro 2006), but with at least some interest in increasing economic activity. ${ }^{1}$ Moreover, varying degrees of integration can be attempted, with bilateral agreements the first rung of the ladder and free trade zones following before more ambitious vehicles such as customs unions and monetary unions can be envisaged (Balassa 1962). Nonetheless, some liberalization is necessary in order to integrate, as the removal of specific trade barriers among member states is by definition a liberalization from the existing arrangements between countries.

But the liberalization which may be required for regional integration can be narrowly circumscribed, limited to negotiated areas, and with little positive externalities for trade in general. In fact, at the same time that integration is creating limited liberalization amongst specific partners, the process may also lead

\footnotetext{
${ }^{1}$ As te Velde (2011:2) notes, "not all regions are formed for economic reasons, yet politicians in all regions are interested in growth effects."
} 
to higher common external tariffs against non-members, the retention of large amounts of non-tariff barriers (NTBs), or the over-use of rules of origin as a restrictive mechanism (Bilal 1998). Thus, integration need not be an unmitigated good for economic openness and could result in a net loss for economic liberalization as a whole.

The reason behind "integration without liberalization" is a familiar one, namely that domestic politics do not stop at the border; in any regional grouping, the nature of the political regime determines how a state may enter into regional cooperation, and countries with more authoritarian or statist governments (Obydenkova and Libman 2019) - or those with little pre-existing commitment to liberalization (Solingen 1997) - are less likely to pursue anything but narrowly-focused and highly managed integration. But while the issue of "authoritarian regionalism" (Libman and Vinokurov 2018) is partly at play here, in that authoritarians may not have incentives for the harmonization which comes with integration, the role of domestic politics goes beyond merely the type of regime. Indeed, broad-based regional integration is often moribund unless there is a strong domestic desire for liberalization under any kind of political regime, which can then translate into political will (see Stubbs [2000] for an example of this with the ASEAN Free Trade Area).

Given that regional economic integration often occurs without any corresponding political integration or developing common institutions (at least not in the earliest stages of integration), political incentives within the integrating countries remain fairly static; put another way, without deep institutional changes within member states, altering the incentive pay-off of protectionism versus liberalization, there is still little reason for politicians to stop policies aimed at protecting a country's industries against other countries, resulting in persistent protection (Nagaoka 1994). As Cadot et al. (1999:651) assert, "a deepintegration [customs union] may end up being even more protectionist than the most protectionist of its members." In the most extreme cases, where regional integration is utilized as a complete substitute for broad-based liberalization, a country may still engage in "protectionism by other means" within the regional grouping itself, using emergency decrees, carve-outs for health and safety, and asking for large swathes of discretion for sensitive or priority industries (Krapohl et al. 2014). In such a situation, as Krueger (1999:119) notes, "It is possible that protectionists will accept [preferential trade agreements] to avoid further multilateral liberalization" but without actually moving towards much liberalization at all.

The purpose of this paper is to examine if the EaEU, as a vehicle for integration (and distinct from the Customs Union set up between Russia, Belarus and Kazakhstan in 2010 which preceded it), has actually increased the liberalization of its members with regard to trade or whether it has, in line with predictions made regarding other examples of regional governance (e.g. Cadot et al. 1999), fallen into a protectionist trap. Other work in this vein has relied on the outcomes of the EaEU process, namely if there has been an increase in trade amongst members and externally (Tarr 2016, Vinokurov 2018), and/or modeling the effects of a decrease in overall trade costs (Knobel et al. 2019) with reference to comparative advantages (Falkowski 2017). Our approach is different: to test Nagaoka's (1994) assertion in the case of the EaEU, we examine the inputs: that is, based on the treaties, agreements, and operations of the EaEU and its constituent bodies and members, did the EaEU create the basis for member states to liberalize their economies? Following on from the injunction of Hartwell (2013) to use the EaEU as a vehicle to overcome domestic opposition to greater trade liberalization, did these five countries actually do it as part of their integrative processes? 
In doing so we subscribe to the view that institutions or regimes, defined in their broadest sense of encompassing the rules of the game, matter to policy outcomes, including liberalization. The area of international trade and economic cooperation, in particular, has become the province of complex bilateral and regional agreements and developed and legalized multilateral frameworks, such the WTO. Such institutions matter not only in terms of the scope and depth of liberalization commitments they embody, but also in the extent to which they ensure their credibility and implementation prospects. As Haftel (2013) argues, high levels of regional trade are associated with greater institutionalization and economic scope, but provided that the implementation of the signed agreements is ensured and accompanied by independent bureaucracies and legalized dispute settlement mechanisms. Focusing on the inputs of trade is also important in so far as developments in Eurasian integration have been associated with changes in its institutional regime: most recently, this was undertaken with the adoption of a Treaty on the Eurasian Economic Union on May 2014 in Astana (the Astana Treaty), which codified and upgraded the framework for economic cooperation established as part of the 2010 Customs Union (Dragneva 2018a).

Our examination of these issues finds that the immovable objects which are the EaEU member states (and above all Russia) have been able to resist the forces of liberalization yet again. Despite tentative steps towards liberalization via integration, especially in the area of tariffs and free movement of people, developments to date have given rise to the reintroduction of internal customs controls, the omnipresence of NTBs, the fragmentation of the customs union, and protectionist external agreements call for skepticism. To put it simply, the de-liberalization dynamics in these areas have the potential not only to cancel out the achievements already made in marginally contributing to liberalization but to affect the credibility of the whole integration project.

Part of this is attributable to the outsize influence which Russia wields within the bloc, and the fact that Russia has never been a champion of trade liberalization in any forum (Hartwell 2016a). With Russia's trade policy dominating the EaEU's approach to liberalization - and especially Russia's willingness to set aside EaEU niceties if the Kremlin feels that a certain trade policy needs to be followed out of national interest - the EaEU has been unable to foster growth. As Hartwell (2016a) notes, the EaEU requires more liberalization to advance and diversify its economies, a fact confirmed by Falkowski (2017) in examining the lack of competitiveness in EaEU economic structures. As of present, the EaEU is lacking a driver but also the institutional vehicle to achieve this goal, and we demonstrate that the institutional set-up of the EaEU is poorly equipped to deliver on its ambitious agenda and implement a break with previous trajectories of limited liberalization domestically or regionally.

While authoritarian or illiberal regional organizations have been deemed effective in launching integration but poor in its implementation (Libman and Obydenkova 2013, 2018), we seek to add nuance this argument by drawing attention to the institutions established at the launch of integration. Indeed, key features of the EaEU's design, such as the incomplete nature of its common regime, the weakness of common bodies and the wide scope for high-level inter-state political bargaining, present not only ex ante limitations but facilitate ex post departures. Despite the effort to emulate supranational regulatory models, such as the European Union, the EaEU centers on the primacy of its member states, has limited capacity to change its domestic dynamics, and enables the continuity of protectionist tendencies. Any progress in addressing these problems is thus dependent on the continued commitment of the member states. In this sense, the pursuit of liberalization and deep economic integration, more generally, is undermined by the fact that the integration bargain is dominated by considerations of geopolitical 
balancing, the need for domestic political consolidation, or the desire to extract specific economic concessions (Dragneva and Wolczuk 2013, 2017; Jonavicius et al. 2018).

The rest of this paper proceeds as follows: the next section examines the history of trade liberalization in the EaEU, with a focus on both internal and external moves towards liberalization. Section III examines the institutional and legal set-up of the EaEU and how it may have contributed to (or hindered) such liberalization. We discuss its implications with regard to the prospects for 'deep' integration within the EaEU but also the EaEU's external policy, in particular its conclusion of free trade agreements (FTAs). A key benefit of the EaEU is that it allowed the member states a mechanism to complete trade agreements with other countries and regional blocs, an institutional arrangement which was missing pre-Union. However, the FTAs that the EaEU have concluded and is on its way to concluding have also shown a decided lack of interest in broad-based liberalization. Finally, Section IV draws our conclusions about the liberalization credentials of Eurasian integration and their implications.

\section{Trade Liberalization in the EaEU: A Brief History}

The Eurasian space, including but beyond the current members of the EaEU, has seen a complicated relationship with trade liberalization over the past thirty years. Unlike their ex-socialist counterparts in Central Europe, already on the way to European Union accession, the countries of Central Asia, the Caucasus, Belarus, and Russia did not embrace trade openness immediately (if at all). Thus, the move towards greater regional integration in any form - which did in fact begin immediately with the fall of the Soviet Union in an attempt to rescue collapsing linkages - has always co-existed uneasily with official wariness towards trade liberalization. This dynamic, of promising liberalization vehicles and entrenched protectionism, has been the key paradox of Eurasian integration.

Independent Countries, Independent Policies

The collapse of the Soviet Union and the freeing of Moscow's satellite states in Central and Eastern Europe - along with the creation of newly independent republics in Eastern Europe, the Caucasus, and Central Asia - meant that the institutions for trade under central planning also imploded, leaving behind sovereigns in need of a trade policy. In the first instance, the Committee for Mutual Economic Assistance (CMEA or Comecon), the barter zone of socialist countries, rapidly fell apart even before the Soviet Union dissolved, voting to disband itself in June 1991. With forced trade patterns longer in place and a collapse of other supporting institutions, the current members of the EaEU were left to forge their own independent trade agreements and policies (while at the same time freeing up trade so that market forces could determine the composition and direction of flows).

As the largest successor state to the USSR and the heart of Eurasian integration, the Russian Federation has had a tempestuous relationship with trade liberalization since 1992. Indeed, as with many other countries, the Kremlin has always viewed its trade policy as inextricably linked with its foreign policies; however, unlike other countries in the West, Moscow has been unwilling to sacrifice political goals in favor of economic ones, meaning that any clash of political and economic goals has resulted in a win for politics. This is not just a matter of philosophy ushered in with Vladimir Putin in 2000 (although he has been a strong proponent of trade policy supporting broader goals), as even in the supposedly wild west of capitalism days of the 1990s, Russia had the least-free trade policy of the current EaEU member states 
(Figure 1). From its earliest days, Russia relied on a series of export restraints (which proved exceedingly difficult to remove, see Tarr [2009]) as well as import subsidization; the World Bank (1993) estimated that import subsidies cost approximately $17.5 \%$ of GDP in 1992 alone! And while the Federation was interested in building its own governmental capacity for trade negotiations, building on its legacy in economic diplomacy, integration into global institutions such as the World Trade Organization (WTO) was less important (more on this below, but this point was made by Dmitriev [2006]). From pushing back on trade agreements with the EU due to human rights "conditionality" (Haukkala 2015) to the persistent (if diminishing) role of state trading organizations with respect to exports (Michalopoulos and Drebentsov 1997), post-Soviet Russia appeared congenitally unable to give itself over to fully embracing trade liberalization. Moreover, "in the wake of Russia's August 1998 financial market and foreign exchange crisis, several countries in the [Commonwealth of Independent States]...re-introduced some trade controls... For instance, Russia re-introduced export tariffs on oil, gas, petrochemicals, metals and a few other goods" (Hare 2001:490), while "temporary" measures introduced earlier in the decade continued to remain entrenched (Tarr 2009).

Figure 1 - Heritage Foundation "Trade Freedom" Score, 1995-2004

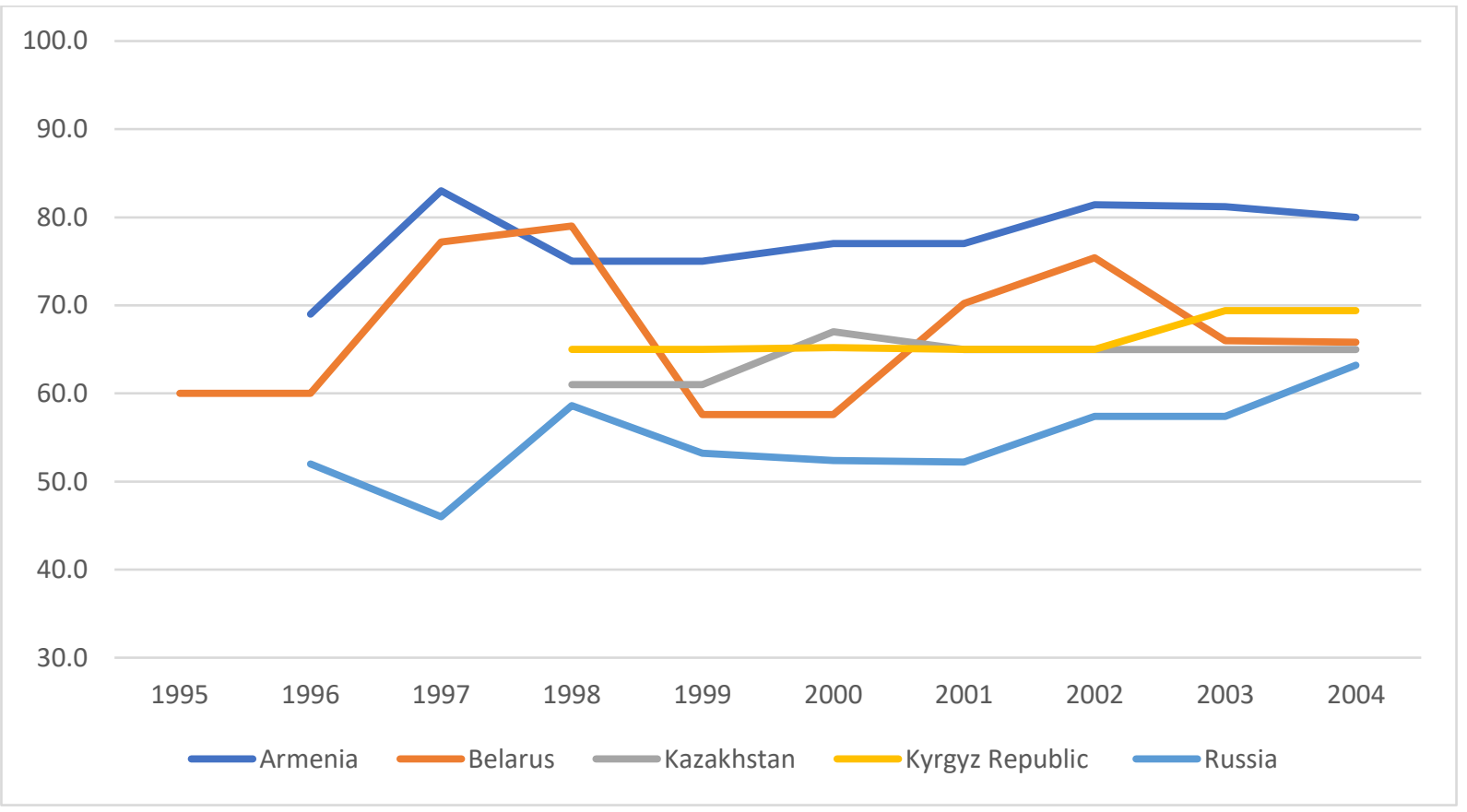

Source: Heritage Foundation. Trade Freedom is scored from 0 to 100, with higher scores representing more freedom.

Of course, Russian President Putin more than anyone else has helped to craft the country's trade policy into a tool of foreign policy, notably transforming Russia's haphazard trade institutions (Tarr 1998) into a weapon deployed against Russia's perceived enemies. Indeed, perhaps more importantly, Putin has helped to legitimize trade sanctions, tariff policies, and embargoes from being mere ploys in negotiations to an ideology or end unto themselves: as Hartwell (2016b: 75-76) notes, “Vladimir Putin's 'Kandidat in Economic Sciences' dissertation from the St Petersburg Mining Academy in 1997 outlines an intensely nationalistic policy where national champions use their market share to disadvantage foreigners while 
retaining low and subsidized prices for the Russian market." While this piece of academic writing is not the ideological basis for the trade policies of the Russian state - if anything it is more an expression of centuries of Russian sentiment towards trade (Von Laue 1954; Kirchner 1981) - it does show how the Presidency as the flagship institution of Russia's political regime rationalized its own approach to a consistent theme in Russian history.

This embrace of the concept of trade policy as political cudgel has translated in the Putin era into an unabashed use of sanctions and tariffs, usually on "safety" grounds, against countries of the former Soviet Union who have run afoul of Moscow's foreign policy aims, including (most prominently) Ukraine, Georgia (Delcour and Wolczuk 2006), and Moldova (Cenusa et al. 2014), but also including current EaEU fellow member Belarus (Hancock 2006). At no point has Russia espoused a defense of unilateral or comprehensive trade liberalization (Pomeranz 2010), preferring to keep non-tariff barriers high with most of its trade partners, including (despite some progress) fellow EaEU members (Isakova et al. 2016). This has translated into low international rankings across the board: in the World Bank's "Doing Business" database for 2019, Russia ranked 99 out of 190 countries for "trading across borders" (much worse than China or Mexico, to take two random comparators) while its trade costs in services are higher than the regional average and prohibitive in the area of logistics and rail freight. ${ }^{2}$

Figure 2 - Heritage Foundation “Trade Freedom" Score for the Smallest EaEU Members, 1995-2019

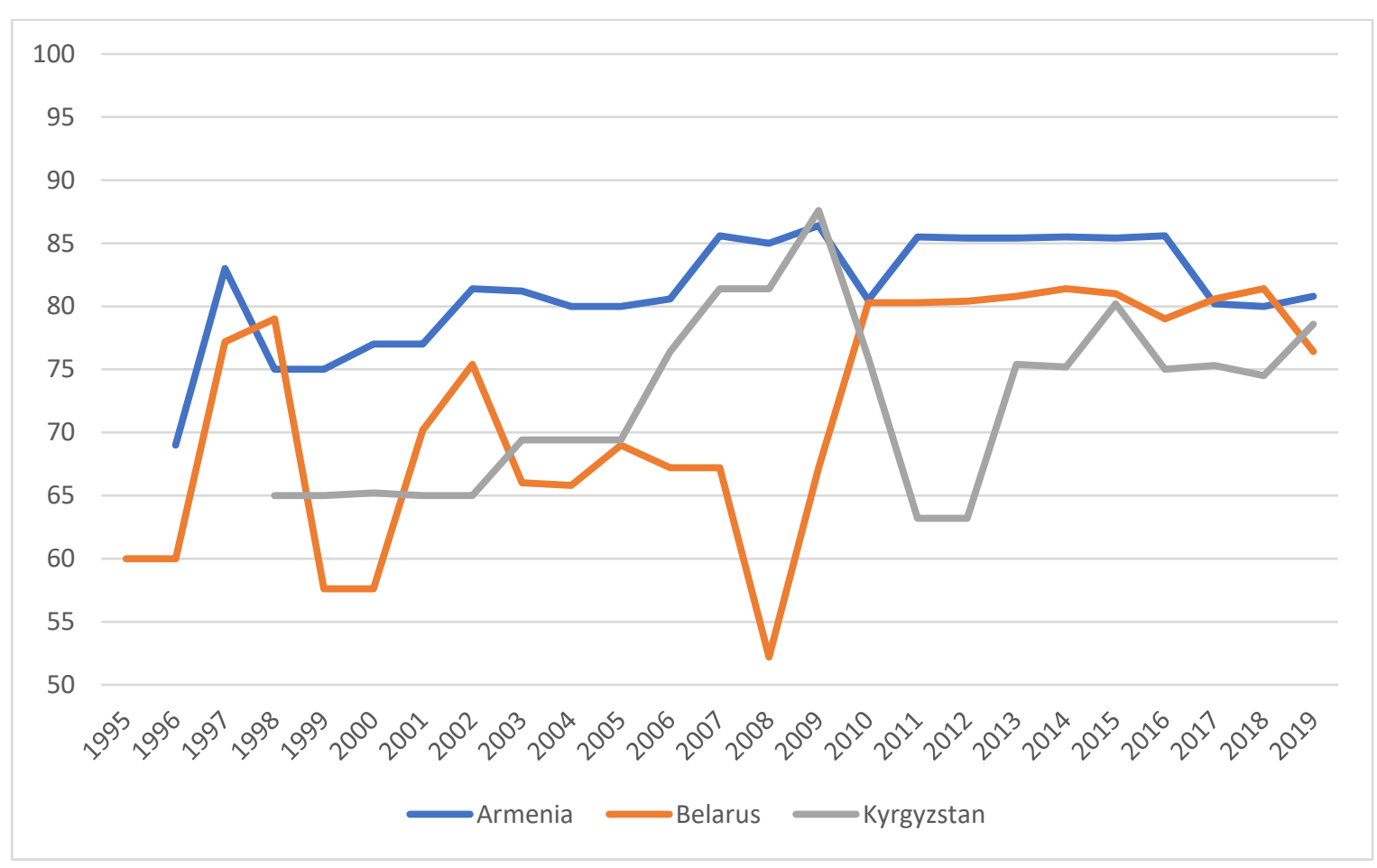

Source: Heritage Foundation. Trade Freedom is scored from 0 to 100, with higher scores representing more freedom.

\footnotetext{
2 Data taken from the World Bank Services Trade Restrictiveness Index, https://tcdata360.worldbank.org/indicators/trade.stri.stri?country=RUS\&indicator=3129\&product=0\&viz=line cha rt\&years $=2014,2016$.
} 
By contrast to Russia, Kazakhstan has undergone a somewhat more successful liberalization of its trade since the collapse of the Soviet Union. According to the Heritage Foundation's Index of Economic Freedom, in the category of "trade freedom," Kazakhstan has increased its score to 80 out of 100 (ranking as "free") from a starting score of 61 in 1997, with a noticeable decline in both tariff and non-tariff barriers - in fact, the maximum rate on Kazakhstan's tariffs is 55\%, a marked drop from Russia's maximum of $100 \%$. Part of the impetus for this more pragmatic policy is the fact that Kazakhstan borders a true economic giant in the guise of China, and thus stands to gain from increased trade (in 2017, China was Kazakhstan's largest destination for exports and second-largest source of imports behind Russia). However, as the Asian Development Bank (2006) noted, Kazakhstan was also no angel when it came to trade liberalization, with tariff schedules that were deceptively small and bureaucratic administration which was arbitrary, capricious, and unpredictable. Additionally, and oddly enough, Kazakhstan's commitment to free trade has been lowest in its immediate neighborhood, with its attitude towards Uzbekistan and Kyrgyzstan (pre-EaEU) deteriorating in a reciprocal spiral of tariffs and barriers (Kurmanalieva 2008).

For the smaller, landlocked (and non-resource rich) states of the EaEU, including Belarus, Armenia, and Kyrgyzstan, trade policy has also been less than ideal in terms of reaching the liberalization frontier, with small volumes befitting their small size but also handicapped by conflict (Armenia), tit-for-tat trade disagreements with neighbors (Kyrgyzstan), and a general lack of commitment to any form of liberalization (Belarus). The internal political strife of Armenia and Kyrgyzstan has made it difficult for either country to chart a consistent course on its external trade policies (see Figure 2), although Armenia has pursued a generally more open trade policy than its fellow EaEU members (Jensen and Tarr 2012) and was the most open member of the Commonwealth of Independent States (CIS) prior to joining the EaEU. Kyrgyzstan also pursued a policy of trade liberalization following its "Tulip Revolution" in 2005 but saw this progress reverse and its trade polices decline precipitously following the global financial crisis and the second revolution in 2010. And while Belarus has had its own trade policies improve in recent years, this is due to it being the main proponent of freer trade with Russia, due simply to Belarus' intense reliance on trade with its neighbor (Frear 2013). In this sense, as we will see below, perhaps the move towards the EaEU improved overall liberalization, even if it was targeted on a smaller set of countries than any move towards general openness.

\section{The WTO Process}

While the current member states of the EaEU have not been stalwart champions of free trade, there have been two instances where trade liberalization has progressed. The first, and largest, impetus for trade opening has been accession to the World Trade Organization (WTO), a process successfully concluded by the Kyrgyz Republic (1998), Armenia (2003), Russia (2012), and Kazakhstan (2015), with Belarus in process since 1993 and promising to join at the next ministerial meeting. As the supranational organization regulating world trade norms and rules, the laborious process of joining the WTO requires extensive harmonization and movement towards the adoption of a complex body of developed rules and the compliance with international procedures.

However, as Figures 1 and 2 above showed, the mere fact of the WTO accession was not enough to force general liberalization for all countries, nor has it prevented the use of trade as a weapon. Shepotylo \& Tarr (2013) show how the WTO process did in fact have a beneficial effect on the lowering of Russian 
tariffs, but the reality has been that Russia's reluctance to liberalization has thus shifted from formal trade barriers to non-tariff barriers. And the continuing bias against liberalization in the services trade (despite a commitment to improve as part of the WTO process) continues to hamper the Russian economy, meaning a large number of gains as predicted by Rutherford and Tarr (2010) have been left on the table.

\section{Eurasian Integration}

The other area where trade liberalization has progressed somewhat has been in the area of regional integration. The EaEU is but one of a web of regional organizations across the Eurasian space arising in the wake of the collapse of the USSR, overlapping with and bumping up against broader political and security organizations such as the CIS (Libman and Obydenkova 2013) and the Shanghai Cooperation Organization (Gatev and Diesen 2016. However, even with this web of organizations in the region, economic cooperation in Eurasia proliferated in the post-Soviet era only at an informal level.

In reality, many Soviet-era economic linkages never went away, due mainly to the specialization created by the planned economy and the value chains linked to these specializations (Lankina et al. 2016). The collapse of the USSR made retaining these value chains a matter of life and death for industries and newly sovereign nations which could not immediately compete on the global stage (Roberts and Moshes 2016). Unfortunately, the turbulence of transition made it difficult to institutionalize any attempts at fostering these value chains (or even developing them beyond their centrally-planned starting point), and the history of formal economic integration in the region is one of uneven progress: starting in 1995 with the signing of an agreement on forming a Customs Union between Belarus, Kazakhstan, and Russia (but mooted almost from the moment the USSR collapsed by former Kazakhstan President Nursultan Nazarbayev in an attempt to keep economic links alive on an inter-state, rather than intra-state, basis), the process of economic integration in the CIS realm suffered many false starts and overlapping initiatives (Hartwell [2013] has an overview of these various initiatives). It was not until the creation of the Customs Union among Russia, Kazakhstan, and Belarus in 2010 that regional economic integration began to truly evolve, as the current members of the EaEU have striven to keep barriers relatively low specifically between each other (the original Customs Union covered only $24 \%$ of tariff lines) while maintaining a relatively high common external tariff (CET) based on Russia's trade policy structure.

Given the spotty record in openness to trade by its individual member states, both on a bilateral and multilateral basis, as well as the deficiency of previously grand but ultimately inconsequential regional projects, the move towards a full-fledged Customs Union in 2010, followed by the constitution of the Eurasian Union in 2015, must have come to outside observers as a surprise. Some tangible successes have been realized as a result of the EaEU: the fact that one may travel from Almaty to Moscow to Minsk to Yerevan without encountering customs controls is a hugely significant change for countries longaccustomed to patrolling their borders intensely, and the planned removal of additional internal trade barriers has appeared to generate new trade flows among the EaEU member states.

Indeed, in one sense, the EaEU has helped countries never enamored with trade liberalization to begin with to see success in one specific and narrowly defined slice of trade liberalization, mainly the consolidation of market access with each other. It appears that the Eurasian project has increased intraregional trade higher from its previous levels, albeit to different extents for different member states; according to numbers from the Eurasian Economic Commission, trade within the bloc rose by 
approximately $31 \%$ by (nominal) value over 2015 to 2018, with the largest increases by percentage and value occurring for Russia (an approximately $35 \%$ increase). These figures are often taken as evidence of the success of the Union in fostering some trade liberalization, including the qualitative improvement in the structure of trade within the EaEU (Vinokurov 2017). Unfortunately, Kofner (2019) points out that the share of intra-EaEU trade has not increased relative to the Union's share with the rest of the world, meaning that the gains may be on trend and not attributable to the EaEU per se. Moreover, the smallest countries, particularly Belarus and Kyrgyzstan, appear to have integrated most into the EaEU's internal market - likely due to their pre-Union reliance on Russia, see Gurova et al. (2018) - and the sharing arrangements within the EaEU have meant a transfer from Belarus to Russia of tariff revenues (Vashchilko 2017).

It appears that, while some liberalization has been achieved as part of the Customs Union/EaEU processes, Eurasian integration has not been an unmitigated success at driving liberalization, consisting more of "declaratory liberalization" than actual tangible progress. As an example, Kazakhstan underwent a partial de-liberalization as part of joining the 2010 Customs Union, adjusting its external tariffs to the higher Russian levels (Isakova et al. 2016). This was also because the CU's external tariff incorporated tariff increases adopted by Russia as part of its extensive protection measures introduced in $2009 .{ }^{3}$ At the same time, given that the launch of the $\mathrm{CU}$ resulted in legal uncertainty and disruption of external trade, for many of its key trading partners, such as the EU, the CU was to serve Russia's protectionist policy (Dragneva 2019).

This tension was played out further in the uneasy relationship between the CU and the WTO. On the one hand, the liberalization credentials of the bloc were asserted with the adoption of the 2011 Treaty on the Functioning of the Customs Union in the Multilateral system following a turbulent episode which put Russia's WTO accession into question (Connolly 2013). The Treaty ensured that Russia's accession commitments became part of the CU framework, to be implemented by the bodies of the Union in areas of delegated competence, such as tariff regulation. It also enshrined the supremacy of WTO rules and their applicability to the bloc's non-WTO members. At the same time, while the 2011 Treaty solution resolved Russia's WTO accession, the situation was not that simple for members acceding to the WTO after Russia, such as Kazakhstan, or members acceding to the EaEU after entering the WTO, such as Armenia and Kyrgyzstan (Movchan and Emerson 2018). For the latter, this entailed a tariff rise to match the EaEU schedule by 2020 for Kyrgyzstan and 2022 for Armenia. Until then both countries were granted significant extensions: for Armenia, for example, they represented 40\% of Armenia's imports from nonEaEU countries. Similarly, both countries were obliged to embark on compensatory negotiations with the WTO in line with these changes.

In the case of Kazakhstan, joining the WTO in 2015 on a more liberal schedule, entailed operating exemptions on about 3,500 tariff lines and representing half of Kazakhstan's imports from non-EaEU countries in 2020 (Movchan and Emerson 2018). Unlike Armenia and Kyrgyzstan, however, at the end of the transition period (in 2024), Kazakhstan will negotiate with its EaEU partners the terms of increase of its tariffs to the EaEU schedule. All this has meant that the EaEU has had to operate as a partial customs union with exemptions covering about a third of the tariff lines in its external tariff (Guicci and Mdinaradze 2017). Importantly, this has also affected the internal fabric of the Union, as it has required the

\footnotetext{
${ }^{3}$ The situation was somewhat relieved by granting Kazakhstan a large number of exemptions (Kassenova 2013), thus operating only a partial customs union from the start.
} 
establishment of a mechanism to monitor the mobility of exempted goods, as will be discussed in the next section. In this sense, the liberalization potential of the EaEU has been limited and may remain so for a long time, especially if Kazakhstan's compensatory negotiations prove to be problematic.

Furthermore, while the EaEU has been charged with implementing Russia's WTO undertakings for reduction of tariffs, this has not been a straightforward process. Successive United States Trade Representative (USTR) reports, for example, have referred to a range of problems in the implementation. In particular, the 2018 report noted that Russia's additional "minimum duties" on some goods may have resulted in combined tariff rates beyond the commitments made to the WTO, while at the same time additional tariffs on US industrial products have triggered a formal dispute settlement proceeding between the US and Russia (USTR 2019).

Finally, international trade theory teaches us that regional economic arrangements can fall prey to "trade diversion," forcing trade into "unnatural" patterns because of preferential agreements. Kazakhstan was projected to have the greatest potential for trade diversion - i.e. from China and the EU towards Russia prior to the EaEU coming into force, and recent evidence shows that Russian companies have indeed made inroads in Kazakhstan where they would not have before (Tarr 2016). Similarly, Armenia's move towards greater trade with the EU also halted dramatically with its abrupt decision to join the EaEU, with Russian companies seeing much greater success exporting to the tiny land-locked country from 2014 onward. Thus, EaEU membership for all countries not named Russia has entailed some measure of trade diversion, meaning an increase in specific liberalization, but not an increase which has resulted in general liberalization.

\section{Institutions for Internal Market Success?}

As already noted, the EaEU set itself the ambitious objective to create a common market with no internal barriers to trade, movement of labor, and movement of capital, predicated on harmonized regulations and standards. Yet, a detailed analysis of the institutional provisions and functioning mode of the EaEU suggests that the feasibility of its liberalization goals has been undermined by important structural features, not least of all in the constitution of its key institutions. Thus, the problems relate not just to implementation but also to both the ex-ante limited commitment when launching the EaEU and subsequent attempts to "upgrade" it through the roadmap for integration.

\section{Scope and credibility of the common regime}

While all countries have had their reasons to commit to integration (Dragneva and Wolczuk 2017), this has not necessarily entailed a willingness to be bound by a comprehensive and developed common regime. Reflecting on the various obstacles to the functioning of the internal market of the Union, the Eurasian Economic Commission itself has raised the issue of limited member states' commitment, resulting in partial integration, or nedointegratsiya. ${ }^{4}$ Its assessment of the existing NTBs in internal trade

\footnotetext{
4 E.g. Interview with Karine Minasian, Minister of the Eurasian Economic Commission, 29 September 2016, http://www.eurasiancommission.org/ru/nae/news/Pages/29-09-2016-1.aspx; “Tigran Sarkisian na PMEF-2019," 7 June 2019, https://xn----8sbeibfw3aojl2n.xn--p1ai/eaes/tigran-sarkisyan-v-vosplamenyayushchemsya-mire\%D0\%B5ek-ne-hvataet-polnomochij/.
} 
reveals that the majority of them are due to the Union regime being not developed or, if in place, allowing member states to deviate from it. ${ }^{5}$

This phenomenon is aptly illustrated by the field of food safety, which has been described not as a workable single food safety system but rather a conglomeration of the national systems of its member states (Sedik et al. 2017). The resulting lack of robust common standards opens the way to divergent domestic interpretations and inconsistencies, multiplication of requirements, or simply lack of capacity to provide a credible system of controls. Moreover, the political commitment to such barriers reduced fundamentally the utility of Eurasian integration, particularly as far as Russia's partners are concerned (Tarr 2016, Vinokurov et al. 2016).

The formal commitments of member states in areas, such as services, transport, investment or procurement, are similarly limited. In these fields, member states have consented to loose interstate cooperation rather than the creation of a unified regime. It is noteworthy that in drafting the EaEU Treaty, such policy areas were vaguely defined as 'coordinated (harmonized)', thus remaining firmly within the realm of member states' discretion (Dragneva 2018a). At the same time, while the creation of a common energy (electricity, gas and oil) market was one of the distinct additions of the EaEU, this process has been planned over several stages due to complete in 2025 and premised on further member states' agreement and action. While some general program documents have been adopted, a range of critical stumbling blocks remain (Kofner 2019), putting into question not only the timetable but also the very ambition of integration.

Thus, it has to be recognized that much of the liberalization potential of Eurasian integration is premised on future action and, therefore, the willingness and ability of member states to develop the regime. This puts a high premium on the continued interest of member states to invest in Eurasian integration. Of particular importance here is Russia's motivation, given its role as the key driving force behind the project. As already noted, for Moscow, the economic benefits of Eurasian integration are far outweighed by its geopolitical functionality (Dragneva and Wolczuk 2013, 2017). As a consequence, developing the technocratic details necessary for integration to succeed has often taken a back seat, with the focus being instead on the speedy symbolic launch of the Union in 2014 and its expansion. This has meant, for example, that projects such as the adoption of a new Customs Code have been delayed: while the need for improved common customs regulation was identified as early as 2010, the Code was adopted only in 2017. Similarly, no serious attention was devoted to non-tariff barriers until late 2016, when a special department of the Commission to deal with barrier to the internal market was set up.

This aspect becomes particularly problematic when combined with Russia's willingness to step back from its commitments at the cost the achievements already made by the bloc. This was most clearly demonstrated in the context of Russia's sanctions war with the West. Failing to secure the consent of its partners for an EaEU-wide response, Russia proceeded on its own to impose import trade bans following its multiple interventions in Ukraine. This unilateral step undermined the very essence of the EaEU as a customs union based on a common external tariff (Knobel et al. 2019). Given the willingness of Belarus

\footnotetext{
${ }^{5}$ See the Data-basis on the functioning of the internal markets, maintained by the Eurasian Economic Commission, whereby of the currently registered 70 obstacles: 38 represent "restrictions," i.e. situations arising out of gaps in the legal regulation at the EaEU level, 14 represent "derogations," whereby member states are allowed to depart from the common regime, and 18 represent "barriers," that is situations resulting from infringements of Union law, https://barriers.eaeunion.org/ru-ru/Pages/obstacles.aspx.
} 
and Kazakhstan to trade in sanctioned goods, this step also had profound effects on the integrity of the internal market. To enforce its import ban, Russia re-introduced border customs and food safety controls. This - along with the mechanism for monitoring the movement of goods exempted from the common external tariff - has led to the emergence of a two-tier customs regime (Kofner 2019). Similar complications have arisen following the transit restrictions imposed on Ukraine's imports in 2016. Russia's decision resulted in higher transaction costs for Kazakhstan and Kyrgyzstan because of longer alternative routes. Bilateral trade in key industrial goods, such as coal, suffered particularly. ${ }^{6}$ While Russia has recently offered some relief, this remains a unilateral concession operated by the issuance of special permits to certain exporters for defined transit volumes by the Russian Ministry of Economic Development and is, thus, affected by domestic political economy considerations.

Against this background, the continued commitment of Russia's EaEU partners is not to be taken for granted either. The EaEU emerged in a context of reawakened sovereignty sensitivities and concerns about Russia's dominance in the region (Vieira 2016). As a result, preserving member states' supremacy and limiting the ambition of integration was an explicit strategy for countries, such as Kazakhstan (Kembayev 2016, Dragneva 2018a). Russia's further unilateral actions have been particularly problematic given their economic cost on its partners. It is not surprising that EaEU member states, such as Armenia, have been keen to continue cooperation with external partners, such as the EU, even in areas that fall within areas of possible EaEU future cooperation. Armenia's Comprehensive Enhanced Partnership Agreement (CEPA) with the EU, for example, contains commitments in public procurement, services, and sectoral cooperation (Dragneva et al. 2017). Thus, while the formal compatibility of the CEPA and Armenia's EaEU current undertakings is not in question, the interest in further integration in these fields cannot be assumed.

\section{Weak common bodies}

Another salient expression of the tension between declared goals and institutional means is the weakness of common bodies within the Union. While simple free trade arrangements do not require developed organizational systems, the ambitious integration objectives of the EaEU depend on the strength of their common organs. The formation of the EaEU included the set-up of an EU-style permanent body, the Eurasian Economic Commission (EEC), yet its potential as an independent common regulator is highly constrained.

The EEC has been endowed with some very important powers in fields such as tariff and customs regulation, the adoption of technical standards, and imposition of trade defense measures. However, the process is embedded in a hierarchical decision-making structure, which means that any of its acts can be revoked or revised by the higher bodies of the EaEU: the Interstate Council and the Supreme Eurasian Economic Council meeting at the level of heads of government and heads of state, respectively (Karliuk 2015, Dragneva 2018a). This means that decision-making within the bloc is ultimately dominated by a political process characterized by high-level interstate bargaining. For example, while the Commission has been empowered to conduct anti-dumping investigations according to a prescribed process and methodology, a 2018 decision against EU herbicide producers which disadvantaged Kazakh consumers

\footnotetext{
6 “Kazakhstan losing \$11 million monthly due to Russia's restrictions on coal transit to Ukraine," Astana Times, 11 November 2019.
} 
was challenged at the level of heads of government. Following protracted negotiations, the Commission was prescribed to amend its decision, which it did in June 2019. ${ }^{7}$ Against such an institutional background, the Commission has often found itself being forced to tread cautiously and conservatively.

Importantly, the Commission's powers are particularly deficient in relation to monitoring member states' practices and enforcing disciplines in the case of infringements (Sedik et al 2017, Dragneva 2018a). The Commission may deem a country to be in breach of Union law and notify it accordingly; indeed, it has done so on many occasions, but this is the limit of its competences. In fact, the EaEU Treaty explicitly removed the possibility for the Commission to resort to the Court in such circumstances. It is notable that in its effort to reassert the primacy of member states, the EaEU Treaty also limited the role of the Court of the Eurasian Economic Union. It restricted the Court's competences and introduced changes with the effect of curbing the ability of the institution to engage in EU-style judicial activism and develop the supranational aspects of the EaEU regime (Kembayev 2016, Karliuk 2017).

Thus, compliance depends on member states' discretion. This is not to say that compliance never occurs in the EaEU. For example, Russia recently amended its rules inhibiting the free movement of sportsmen, following an advisory opinion of the Court issued in December 2018. Yet, it takes place within a context that favors relative power-based solutions rather than predictable and transparent rule-based ones. This has been aptly illustrated during the numerous high-profile 'trade wars' within the Union and particularly Russia's use of sanitary and phytosanitary measures to restrict meat and dairy imports from Belarus. Minsk, however, has perceived such measures to be discriminatory, politically motivated and working against the spirit of integration for a long time. While the Commission has found Russia to be noncompliant, ${ }^{8}$ solutions have depended on highest-level bilateral negotiations intertwined with wider issues around geopolitical loyalty, security or the provision of particular benefits, often outside the scope of the EaEU.

\section{Protectionist external agreements}

It can be argued that these limitations in institutional design create similar constraints to liberalization in developing the external trade agenda of the EaEU. Structurally, the share of EaEU's external trade is much higher than that of internal trade compared to regional organizations, such as the EU (Giucci and Mdinaradze 2017). From this point of view, the EaEU has the potential to create new opportunities for exporters and promote trade liberalization. In theory, it also has the potential to offer a negotiating advantage to small states who, being part in a bloc, have the chance to benefit from an improved bargaining power vis-à-vis third countries.

In this respect, the launch of the EaEU was a major breakthrough relative to previous stages of Eurasian integration in that it set up the EaEU as an international organization with its own independent legal personality. This means that the bloc is capable of entering into international agreements in its own name and through its own bodies. Indeed, since its launch the EaEU has been keen to show itself as a dynamic global actor. To date, the bloc has signed free trade agreements with Vietnam (2015), Iran (2018),

\footnotetext{
${ }^{7}$ See, Decision of the Eurasian Intergovernmental Council $\mathrm{Nr} 4$ of 30 April 2019, followed by Decision of the Collegium of the Eurasian Economic Commission Nr 104 of 18 June 2019.

${ }^{8}$ E.g. Decision of the Collegium of the Eurasian Economic Commission Nr 11 of 22 January 2019.
} 
Singapore (2019) and Serbia (2019), and a non-preferential cooperation agreement with China (2018). Agreements with Egypt, Israel and India are also under negotiation. Yet, as with internal market liberalization, a more detailed look at the institutional set-up for external relations as well as the record so far calls for skepticism. The big prize has been political, including securing external agreements for the Union, thus enhancing its symbolic global standing.

Institutionally, the image of the EaEU as a unified actor is compromised by the already mentioned weakness of Eurasian Economic Commission and the primacy of member states' interest. Given the limited scope of formal powers transferred to the EaEU, the Commission has no powers to negotiate in matters remaining within member states' competence, such as services or investment. Even more importantly, however, the EaEU has opted for a negotiating process which puts member states firmly in control: even in matters within its own powers, the Commission does not negotiate on its own but is always together with member states (Dragneva 2018b). This reinforces Russia's control over the external agenda of the organization but also its limited liberalization potential.

Despite the formal equality between EaEU's member states, it is Russia who has been the driving force behind the external agenda of the Union, particularly the selection of its negotiating partners. In doing so, and even to a greater degree than in relation to the internal agenda of the EaEU, Moscow has followed its geopolitical priorities. The main attraction of entering a free trade agreement with Vietnam in 2015, for example, was not its trade importance but its significance as representing the economic dimension of an important geopolitical shift (Fedorov 2017). The agreement was built on Russia's traditionally close political relations with Vietnam, while seeking to establish a strategic partner in the Asia Pacific, thus achieving multipolarity in Eurasia in the face of rising Beijing. Moscow's leadership has been notable in relations with China as well. Also in East Asia, Russia has been the driving force behind an FTA with South Korea; rumors about such an FTA have been circulating since 2017, but the process faded away for a range of reasons, including the opposition of Russian producers to key South Korean products.

Similarly, the moves towards linking the EaEU with China's Belt and Road Initiative was a Russian strategy announced at a high-level bilateral meeting without prior consultation with its EaEU partners. While the project was endorsed at a subsequent EaEU summit, it has not removed the preference of those partners to deal with China on a bilateral basis. Embarking on a trade agreement with Iran, while highly problematic in WTO terms and riddled with practical complications, was related to Russia's policies in Syria and its regional rivalry with the US, in an effort to strengthen Teheran's role as a strategic ally in the Middle East (Dragneva 2018b). Similarly, the agreement with Serbia is a further step in Russia's tactical game vis-à-vis the EU in the Western Balkans (Bechev 2019).

Table 1: Trade with EaEU's FTA partners as a share in external trade, 2018

\begin{tabular}{|c|c|c|c|c|}
\hline & Vietnam & Iran & Singapore & Serbia \\
\hline EaEU & 0.89 & 0.36 & 0.56 & 0.30 \\
\hline Russia & 0.96 & 0.28 & 0.58 & 0.33 \\
\hline Armenia & 0.39 & 6.91 & 0.04 & 0.07 \\
\hline Belarus & 0.32 & 0.17 & 0.14 & 0.42 \\
\hline Kazakhstan & 0.63 & 0.70 & 0.70 & 0.04 \\
\hline Kyrgyzstan & 0.17 & 0.64 & 0.04 & 0.28 \\
\hline
\end{tabular}

Source: Compiled on the basis of statistics of the Eurasian Economic Commission 
Unsurprisingly, in economic terms, none of these countries are major trading partners for the EaEU or its member states and are therefore of marginal economic significance (Table 1). This is even more so for Russia's EaEU partners, given Russia's overwhelming preponderance in EaEU's trade with these countries (Table 2). Partners acquiesce to Russia's leadership as part of the overall integration bargain, but also, ironically, because trade is small. At the same time, consensus has depended on minimizing the costs of these agreements by enhancing their protectionist nature, as will be discussed below. ${ }^{9}$ Despite this, for example, trade with Vietnam has declined for some of the EaEU members (Bhutia 2019).

Table 2: Member state's share in EaEU's trade with FTA partners, 2018

\begin{tabular}{|c|c|c|c|c|}
\hline & Vietnam & Iran & Singapore & Serbia \\
\hline Russia & 90.9 & 64.2 & 86.4 & 91.6 \\
\hline Armenia & 0.3 & 13.4 & 0.1 & 0.2 \\
\hline Belarus & 1.7 & 2.3 & 1.2 & 6.5 \\
\hline Kazakhstan & 7.0 & 19.1 & 12.3 & 1.2 \\
\hline Kyrgyzstan & 0.1 & 1.0 & 0.0 & 0.5 \\
\hline
\end{tabular}

Source: Compiled on the basis of statistics of the Eurasian Economic Commission

In terms of trade in goods, the extent of liberalization commitments under the EaEU agreements is limited. The agreement with Vietnam covers $88 \%$ of mutual trade in goods, with $59 \%$ of tariffs eliminated upon its entry into force in October 2016 and the rest to be reduced over a 5-10-year period. The EaEU will open its market to Vietnamese exports with an average tariff reduction from 9.7 to $2 \%$ by 2025 . Outside the scope of the agreement remain products deemed most sensitive to the EaEU market, such as milk, meat, and sugar. Furthermore, the EaEU reserves the asymmetric right to apply trigger safeguard measures to control the volume of other sensitive imports, such as rice or textiles. Finally, the agreement allows for protectionist measures to be put in place in the form of quotas or the application of various non-tariff barriers. $^{10}$

The agreement with Iran is another case in point. It is a temporary agreement with a very limited scope: it covers a short list of commodities, representing $50 \%$ of existing trade, and envisages few trade concessions. The EaEU liberalizes mostly non-sensitive goods, whereas trade in competing goods, such as tomatoes or cucumbers, is restricted to seasonal preferences. On Iran's side the commitments are also limited and subject to the protectionist features of its domestic regulation, including a minimum tariff reduction threshold of $4 \%$. Indeed, in the words of EaEU's Trade Minister, the aim of the deal has been to strengthen the position of existing exported goods rather than secure new market access. ${ }^{11}$

In this respect, the EaEU's new agreements are even more marginal. Singapore already operates dutyfree access, whereas the agreement with Serbia consolidates the bilateral agreements Russia, Belarus, and Kazakhstan already had with the country. While the latter arrangements are extended to Armenia and Kyrgyzstan, given the limited volumes of trade the expected gains are minimal.

\footnotetext{
${ }^{9}$ A 2013 assessment of the prospective benefits of an FTA with Vietnam, for example, pointed to a range of disadvantageous effects on Belarus.

${ }^{10}$ Vietnamese rice, for example, is subject to a 10,000 -ton quota, which is less than $5 \%$ of total imports from third countries and applies to long-grain rice, which is not grown within the EaEU.

11 "Nikishina: zona svobodnoi torgovli Irana I EAES - novyi shag k sotrudnichestvu." Sputnik, 17 May 2018, http://sputnik.by/economy/20180517/1035467217/zona-svobodnoj-torgovli-irana-i-eaehs.html.
} 
Similarly, it is unlikely that the planned FTA agreements with India, Israel, or Egypt will break this pattern (Dragneva 2018b). The 2018 agreement concluded with China is not a preferential free trade agreement, but a deal that provides for procedural cooperation and exchange of information on the basis of existing WTO arrangements. Indeed, there is little appetite to open EaEU markets to Chinese goods anymore (if there ever actually was). The same can be said about relations with the EU. While a trade agreement with Brussels is highly unlikely to emerge in the short run, as high level EaEU officials have already stated, it is even more unlikely that such an agreement may contain a trade liberalization component (IIASA 2017).

It is also important to point out that even where market access has been negotiated, the realization of any benefits remains premised on the elimination of regulatory barriers to trade. The case of trade with ran aptly illustrates the vital need for basic payments, logistical and transport infrastructure (Kurbangulova 2018). In particular, Armenia is the only EaEU country to share a land border with Iran and has been keen to increase its trade with the country. Yet, it has suffered from underdeveloped transport links, complicated by sensitive regional dynamics and limited finance to invest in the development of complex infrastructure. ${ }^{12}$

Unsurprisingly, the real benefits of these agreements do not relate to the liberalization of trade in goods, but the extent to which they open the door to increased investment and wider economic cooperation. The agreement with Vietnam, for example, contains a chapter on trade in services, investment, and labour movement, which applies only to Russia. Indeed, much of the impetus for closer relations was driven by the interest of Russian vehicle manufacturers, keen to exploit joint venture opportunities and develop their presence in the ASEAN markets (Dragneva 2018b). Similarly, services and investment are the main attraction in developing relations with Singapore. It is wise to remember, however, that advances in these areas require advances in corresponding internal developments, including the elimination of critical NTBs, something identified by many policymakers and researchers as a key weakness of Eurasian integration.

\section{Conclusions}

Can regional integration occur without a corresponding jump in liberalization? Economic theory suggests that it can, and empirical studies of different regional arrangements suggest that it is far more likely than one would expect. This paper has delved into the integration experience of the countries of the Eurasian Union and found one more piece of evidence supporting the idea of integration without liberalization. Despite a myriad of integration processes over the past decade, beginning with the major leap forward towards a customs union and proceeding swiftly to an economic union, the five members of the EaEU have barely progressed in their liberalization of trade.

We have shown throughout this paper that the drivers of this performance are legion, but perhaps the most important contribution is that the EaEU, as a regional organization, has not created the institutional framework conducive to facilitating liberalization. On the face of it, the EaEU strives to be WTO-compliant and subscribe to a liberalization narrative. However, its very design has undermined this objective. Placing member states in firm control of the organization, amplified by Russia's dominance of the bloc (and its willingness to uniformly set aside economic goals for (geo)political ones), as well as the reality that none

12 “Armenia shelves Iranian railway project as Azerbaijan steams ahead," Eurasianet, 27 July 2018, https://eurasianet.org/armenia-shelves-iranian-railway-project-as-azerbaijan-steams-ahead. 
of the members have been zealots for liberalization pre-EaEU, has dampened its stated ambition. While some successes have been achieved in forging an internal market within the EaEU, the fact that unfettered trade is still scorned can be clearly seen in the EaEU's external agreements, which are geopolitically driven, highly managed, and narrowly circumscribed treaties (and not necessarily driven by economic trends). While it can be argued that the EaEU is still in the making, the features of the initial design combined with its unravelling through Russia's unilateral actions, make it unlikely that protectionist pressures will recede.

In some sense, this state of affairs should not be surprising, as it is difficult to create liberalization at the supra-national level if it does not exist at the national level. On the other hand, liberalization created at the regional level may vitiate the arguments of protectionists and demonstrate the benefits of free trade to the populace. In the Eurasian case, it appears that the overriding need for member state governments to control political developments, coupled with the lack of access to the political system in nearly every member state, means that the veto power of the consumer is severely limited. In that sense, it is more important to focus less on the "regionalism" in "authoritarian regionalism" and more on the "authoritarian" side to understand the absence of constituencies for liberalization. Unfortunately, as noted above, this is compounded by the fact that many Soviet-era linkages (especially in energy) have not evolved beyond their communist past, enhancing resistance to liberalization and reforms at the national level, creating vested interests for protectionism. Without a shift in national politics or the breaking away of a member state with Russia's protectionist policies (likely Kazakhstan, as it is the only one with comparable clout), the EaEU is destined to continue as a makeshift integration arrangement lacking any real move towards liberalization.

\section{REFERENCES}

Asian Development Bank (2006). Central Asia: increasing gains from trade through regional cooperation in trade policy, transport, and customs transit. Manila: Asian Development Bank.

Baer, W., Cavalcanti, T., \& Silva, P. (2002). Economic integration without policy coordination: the case of Mercosur. Emerging Markets Review, 3(3), 269-291.

Balassa, B. (1962). The theory of economic integration. London: Routledge.

Bechev, D. (2019). Russia's strategic interests and tools of influence in the Western Balkans. New Atlanticist, 20 December 2019, https://www.atlanticcouncil.org/blogs/new-atlanticist/russia-strategicinterests-and-tools-of-influence-in-the-western-balkans.

Bilal, S. (1998). Political economy considerations on the supply of trade protection in regional integration agreements. JCMS: Journal of Common Market Studies, 36(1), 1-32.

Cadot, O., De Melo, J., \& Olarreaga, M. (1999). Regional integration and lobbying for tariffs against nonmembers. International Economic Review, 40(3), 635-658.

Cenusa, D., Emerson, M., Kovziridze, T., \& Movchan, V. (2014). Russia's Punitive Trade Policy Measures Towards Ukraine, Moldova and Georgia. CEPS Working Documents, (400). 
Connolly, R. (2013). Russia, the Eurasian Customs Union and the WTO. Dragneva, R. and Wolczuk. K. eds. Eurasian economic integration: Law policy and politics, 61-80.

Damro, C. (2006). The Political Economy of Regional Trade Agreements. Bartels, L. and Ortino, F. Regional Trade Agreements and the WTO Legal System, OUP, 23-42.

Delcour, L., \& Wolczuk, K. (2015). Spoiler or facilitator of democratization? Russia's role in Georgia and Ukraine. Democratization, 22(3), 459-478.

Dmitriev, M. (2006). The need for a trade strategy for Russia. In Foreign trade policy in Russia: Proceedings of the conference on Building Institutions for Evidence Based Trade Policy Decision-Making: International Experience and Russian Strategy. London, 26-27 October 2006. London: European Bank for Reconstruction and Development, available at http://siteresources.worldbank.org/INTRANETTRADE/Resources/WBI-

Training/London_Conference_Proceedings.pdf.

Dragneva, R. (2018a). The Eurasian Economic Union: Balancing Sovereignty and integration. In Post-Soviet Constitutions and Challenges of Regional Integration (pp. 48-70). London: Routledge.

Dragneva, R. (2018b). The Eurasian Economic Union: Putin's Geopolitical Project. FPRI Research paper, https://www.fpri.org/wp-content/uploads/2018/10/rpe-6-dragneva-final2.pdf.

Dragneva, R. (2019). Pork, Peace and Principles: the Relations between the EU and the Eurasian Economic Union. IEL Working Paper, http://epapers.bham.ac.uk/3219/1/IEL_Working_Paper_02-2019_DragnevaLewers.pdf.

Dragneva, R. \& Wolczuk, K. eds. (2013). Eurasian economic integration: Law policy and politics, Edward Elgar.

Dragneva, R. \& Wolczuk, K. (2017) The Eurasian Economic Union: Deals, Rules and the Exercise of Power. Chatham House Research Maper, https://www.chathamhouse.org/sites/default/files/publications/research/2017-05-02-eurasianeconomic-union-dragneva-wolczuk.pdf.

Dragneva, R., Delcour, L. and Jonavicius, L. (2017). Assessing Legal and Political Compatibility between the European Union Engagement Strategies and Membership of the Eurasian Economic Union', EU-STRAT Working Paper Nr. 7, http://eu-strat.eu/wp-content/uploads/2016/05/EU-STRAT-Working-PaperNo.7.pdf.

Falkowski, K. (2017). Long-term comparative advantages of the Eurasian Economic Union member states in international trade. International Journal of Management and Economics, 53(4), 27-49.

Fedorov, N. (2017). Soglashenie o zone svobodnoi torgovli mezhdu EAES I V'etnamom kak factor RosiiskoV'etnamskikh otnoshenii. Sravnitel'naia Politika I Geopolitika, 9(1), 74-90.

Frear, M. (2013). Belarus: player and pawn in the integration game. Dragneva, R. and Wolczuk. K. eds. Eurasian economic integration: Law policy and politics, 119-139.

Gatev, I., \& Diesen, G. (2016). Eurasian encounters: The Eurasian economic union and the Shanghai cooperation organisation. European Politics and Society, 17(sup1), 133-150. 
Giucci, R., Mdinaradze, A. (2017). The Eurasian Economic Union - an analysis from a trade policy perspective. Berlin Economics, 11 April 2017, https://wiiw.ac.at/files/events/giucci-eaeu-11-april-2017en-n-341.pdf.

Gurova, I. P., Platonova, I. N., \& Maksakova, M. A. (2018). The level of trade integration in the Eurasian economic union. Studies on Russian Economic Development, 29(4), 447-453.

Haftel, Y. (2013). Commerce and institutions: Trade, scope, and the design of regional economic organizations'. Review of international Organizations, 8, 389-414.

Hancock, K. J. (2006). The semi-sovereign state: Belarus and the Russian neo-empire. Foreign policy analysis, 2(2), 117-136.

Hare, P. (2001). Trade policy during the transition: Lessons from the 1990s. World Economy, 24(4), 433452.

Hartwell, C. A. (2013). A Eurasian (or a Soviet) Union? Consequences of further economic integration in the Commonwealth of Independent States. Business Horizons, 56(4), 411-420.

Hartwell, C. A. (2016a). Improving competitiveness in the member states of the Eurasian Economic Union: a blueprint for the next decade. Post-Communist Economies, 28(1), 49-71.

Hartwell, C.A. (2016b). Economic Relations between the EU and Russia: Sanctioning Failure? In Nitoiu, C. (ed.), Avoiding a New 'Cold War:' The Future of EU-Russia Relations in the Context of the Ukraine Crisis. LSE Ideas Special Report SR020, March, available at https://www.stiftungmercator.de/media/downloads/3_Publikationen/LSE-IDEAS-Avoiding-a-New-Cold-War.pdf.

Haukkala, H. (2015). From cooperative to contested Europe? The conflict in Ukraine as a culmination of a long-term crisis in EU-Russia relations. Journal of Contemporary European Studies, 23(1), 25-40.

IIASA (2017). Challenges and Opportunities for Economic Integration within a Wider European and Eurasian Space. Workshop Report, August. http://pure.iiasa.ac.at/id/eprint/14899/1/Highlevel\%20meeting\%20June_Workshop\%20report.pdf.

Isakova, A., Koczan, Z., \& Plekhanov, A. (2016). How much do tariffs matter? Evidence from the customs union of Belarus, Kazakhstan and Russia. Journal of Economic Policy Reform, 19(2), 166-184.

Jensen, J., \& Tarr, D. G. (2012). Deep trade policy options for Armenia: The importance of trade facilitation, services and standards liberalization. Economics: The Open-Access, Open-Assessment E-Journal, 6, 1.

Jonavicius, L., Delcour, L., Dragneva, R. \& Wolczuk, K. (2019). Russia's Interests, Strategies and Instruments in the Common Neighbourhood. EU-STRAT Working Paper Nr 16/March 2019, http://eu-strat.eu/wpcontent/uploads/2019/03/EU-STRAT-Working-Paper-No.-16.pdf.

Kassenova, N. (2013). Kazakhstan and Eurasian Economic Integration: quick start, mixed results and uncertain future. Dragneva, R. and Wolczuk. K. eds. Eurasian economic integration: Law policy and politics, 139-162.

Karliuk, M. (2015). The Eurasian Economic Union: an EU-like Legal Order in the Post-Soviet Space? HSE Working Paper BPR/LAW/2015. https://papers.ssrn.com/sol3/papers.cfm?abstract_id=2664519. 
Kembayev, Z. (2016). Regional Integration in Eurasia: The Legal and Political Framework. RCEEL 41, 157194.

Kirchner, W. (1981). Russian Tariffs and Foreign Industries before 1914: The German Entrepreneur's Perspective. The Journal of Economic History, 41 (2), 361-379.

Knobel, A., Lipin, A., Malokostov, A., Tarr, D. G., \& Turdyeva, N. (2019). Deep integration in the Eurasian Economic Union: what are the benefits of successful implementation or wider liberalization? Eurasian Geography and Economics, 1-34.

Kofner, Y. (2019). Did the EaEU create a common market for goods, services, capital and labour within the Union? ISP, 30 October 2019, https://www.institutfuersicherheit.at/did-the-eurasian-economic-unioneaeu-create-a-common-market-for-goods-services-capital-and-labor-within-the-union/.

Krapohl, S., Meissner, K. L., \& Muntschick, J. (2014). Regional Powers as Leaders or R ambos? The Ambivalent Behaviour of Brazil and South Africa in Regional Economic Integration. JCMS: Journal of Common Market Studies, 52(4), 879-895.

Krueger, A. O. (1999). Are preferential trading arrangements trade-liberalizing or protectionist? Journal of Economic Perspectives, 13(4), 105-124.

Kurbangulova, R. (2018). Vremennoe soglashenie ZST EAES-Iran: vyzovy I perspektivy dl'a evraziiskogo biznesa. Eurasian Studies, 10 June 2018, http;//Eurasian-studies.org/archives/8772.

Kurmanalieva, E. (2008). Empirical analysis of Kyrgyz trade patterns. Eurasian Journal of Business and Economics, 1(1), 83-97.

Lankina, T., Libman, A., \& Obydenkova, A. (2016). Authoritarian and democratic diffusion in postcommunist regions. Comparative political studies, 49(12), 1599-1629.

Libman, A., \& Obydenkova, A. (2013). Informal governance and participation in non-democratic international organizations. The Review of International Organizations, 8(2), 221-243.

Libman, A., \& Vinokurov, E. (2018). Autocracies and regional integration: the Eurasian case. PostCommunist Economies, 30(3), 334-364.

Michalopoulos, C., \& Drebentsov, V. (1997). Observations on state trading in the Russian economy. PostSoviet Geography and Economics, 38, 264-275.

Movchan, V. , Emerson, M. (2018). The Eurasian Economic Union's problematic customs union. CEPS, 11 January 2018, https://3dcftas.eu/publications/the-eurasian-economic-union's-problematic-customsunion

Nagaoka, S. (1994). Does Regional Integration Promote Global Liberalization? A Case of Endogenous Protection. Journal of the Japanese and International Economies, 8(4), 551-564.

Obydenkova, A. V., \& Libman, A. (2019). Authoritarian Regionalism in the World of International Organizations: Global Perspective and the Eurasian Enigma. Oxford, UK: Oxford University Press.

Pomeranz, W. E. (2010). Russian protectionism and the strategic sectors law. American University International Law Review, 25(2), 2. 
Roberts, S. P., \& Moshes, A. (2016). The Eurasian Economic Union: a case of reproductive integration? Post-Soviet Affairs, 32(6), 542-565.

Rutherford, T. F., \& Tarr, D. G. (2010). Regional impacts of liberalization of barriers against foreign direct investment in services: The case of Russia's accession to the WTO. Review of International Economics, 18(1), 30-46.

Sedik, D., Ulbricht, C. \& Dzamankulov, N. (2017) The Architecture of Food Safety Control Across Eurasia: the European Union and the Eurasian Economic Union. Lambert Academic Publishing.

Sergi, B. S. (2018). Putin's and Russian-led Eurasian Economic Union: A hybrid half-economics and halfpolitical "Janus Bifrons". Journal of Eurasian studies, 9(1), 52-60.

Shepotylo, O., \& Tarr, D. G. (2013). Impact of WTO accession on the bound and applied tariff rates of Russia. Eastern European Economics, 51(5), 5-45.

Solingen, E. (1997). Economic liberalization, political coalitions, and emerging regional orders. In Lake, D.A. \& Morgan, P.M. (eds.), Regional orders: building security in a new world. University Park, PA: Penn State Press, pp. 68-100.

Stubbs, R. (2000). Signing on to liberalization: AFTA and the politics of regional economic cooperation. The Pacific Review, 13(2), 297-318.

Tarr, D. (1998). Design of tariff policy for Russia. World Bank discussion papers, 7-30.

Tarr, D.G. (2009). Political Economy of Russian Trade Policy: Early Transition, Customs Unions, WTO Accession and Protection for Industrial Diversification. Available at SSRN: https://ssrn.com/abstract=1396813 or http://dx.doi.org/10.2139/ssrn.1396813.

Tarr, D. G. (2016). The Eurasian Economic Union of Russia, Belarus, Kazakhstan, Armenia, and the Kyrgyz Republic: Can It Succeed Where Its Predecessor Failed? Eastern European Economics, 54(1), 1-22.

te Velde, D. W. (2011). Regional Integration, Growth and Convergence. Journal of Economic Integration, 26(1), 1.

United States Trade Representative (USTR)(2019). 2018 Report on the Implementation and Enforcement of Russia's WTO Commitments. Washington DC: United States Trade Representative. Available at: https://ustr.gov/sites/default/files/Russia-2018-WTO-Report.pdf.

Vashchilko, A. (2017). Effects of trade wars on Belarus. V Applied Economics Quarterly, 63(1), 81.

Vieira, A.V.G. (2016). Eurasian integration: elite perspectives before and after the Ukraine crisis. PostSoviet Affairs, 32(6), 566-580.

Vinokurov, E. (2017). Eurasian Economic Union: Current state and preliminary results. Russian Journal of Economics, 3(1), 54-70.

Vinokurov, E. (2018). Introduction to the Eurasian Economic Union. Basingstoke: Palgrave Macmillan.

Von Laue, T. H. (1954). A secret memorandum of Sergei Witte on the industrialization of imperial Russia. The Journal of Modern History, 26(1), 60-74. 
World Bank (1993). Russian Federation - Joining the world economy (English). Washington, DC: World Bank. Available at http://documents.worldbank.org/curated/en/206881468094161066/RussianFederation-Joining-the-world-economy. 